\title{
Dueling Jackpots: Are Competing Lotto Games Complements or Substitutes?
}

By

Victor A. Matheson

and

Kent Grote

Revised version, May 2005

\section{COLLEGE OF THE HOLY CROSS, DEPARTMENT OF ECONOMICS}

FACULTY RESEARCH SERIES, PAPER NO. 04-06

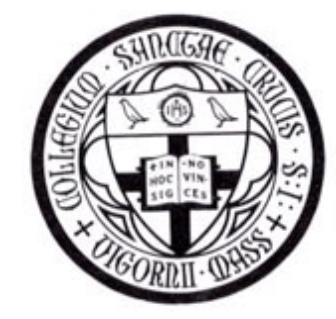

Department of Economics

College of the Holy Cross

Box 45A

Worcester, Massachusetts 01610

(508) 793-3362 (phone)

(508) 793-3710 (fax)

http://www.holycross.edu/departments/economics/website 


\title{
Dueling Jackpots: Are Competing Lotto Games Complements or Substitutes?
}

\author{
By \\ Victor A. Matheson ${ }^{\dagger}$ \\ College of the Holy Cross \\ and \\ Kent Grote ${ }^{\dagger \dagger}$ \\ Lake Forest College
}

Revised version, May 2005

\begin{abstract}
This paper considers the relationship that exists between two lottery products offered simultaneously in the same state, a smaller lottery game run by the individual state and a larger multi-state game run in coordination with other states. The primary issue is whether the two different products should be considered substitutes or complements for one another. The question is considered from two different perspectives that lead to a conclusion that while the two products do tend to be complements to one another, overall the individually run state lottery games experience a reduction in sales from the presence of the multi-state game.
\end{abstract}

JEL Classification Codes: D81, H71, L83

Keywords: lotto, lottery, public finance

'Victor A. Matheson, Department of Economics, Box 157A, College of the Holy Cross, Worcester, MA 01610-2395, 508-793-2649 (phone), 508-793-3710 (fax), vmatheso@holycross.edu

†Kent Grote, Department of Economics and Business, Lake Forest College, Lake Forest, IL 60045, 847-735-5196 (phone), 847-735-6193 (fax), grote@lfc.edu 


\section{Introduction}

While national, state, and local governments offer a variety of legalized gambling products through lottery associations, among the most popular, and the focus of this study, is the set of games known as "lotto," where players select five or six numbers from among 35 to 55 choices (depending on the structure of the game) and win prizes based on the numbers that are correctly matched in a weekly or bi-weekly drawing. A ticket buyer(s) who matches all of the numbers wins the jackpot prize pool while players matching some but not all of the winning numbers win smaller consolation prizes. In most games, if the jackpot prize is not won in a particular drawing, the money allocated to the jackpot is carried over into the next drawing and is added to funds from ticket sales in the next period. Because the jackpot prize fund is allowed to roll-over in this manner, the jackpot prize can become quite large if no one hits the jackpot in a number of successive periods. Indeed, advertised jackpots exceeding $\$ 50$ million are quite common, and occasionally lotto jackpots have been known to exceed \$250 million.

As of June 2005, 40 states had government run lotteries. Each of those states offered some version of a lotto game either through an individually run statewide game or through a multi-state association such as the twenty-seven state Multi-State Lottery Association (Powerball) or the eleven state Big Game/Mega-Millions association. While the prizes, odds, structures, ticket costs, drawing dates, and other elements of the game all differ across the various games, they are all similar in that they offer the opportunity to potentially turn a one dollar ticket into millions of dollars of winnings (albeit with a very low probability.) It is likely the attraction of "making it big" combined with the ease of participation in such games that entices people to take part in this nationwide activity. Added to that, the proceeds from state lottery ticket sales go into the financing of public projects and programs (often times earmarked 
for specific purposes), making lottery tickets a more "conscientious" choice for some gamblers than privately run casinos and race tracks. Several authors have questioned, however, whether earmarked lottery funds do serve to increase spending for the designated area. See Novarro (2005).

In the 1970s and 1980s, lottery associations began to experiment with the idea that by offering games with longer odds but bigger grand-prizes, they could attract more buyers. Forrest, et al, (2002) have suggested that lotto players are attracted by the high jackpots and not the expected return, and lotto is popular due to the "skewness" of the bet rather than its expected return. Lottery associations realized, however, that if the odds were too high, jackpots would be won very infrequently, and, therefore, the games would not benefit from frequent media exposure surrounding jackpot winners. Lottery officials were forced to choose between offering games with high jackpots and ones with frequent winners.

To this end, in the mid 1970s, state and provincial lottery associations began to join together to offer lotto games beginning with the formation of the Western Canada Lottery Corporation in 1974, the Tri-State Lotto, joining Maine, New Hampshire, and Vermont, in 1985, the Multi-State Lottery Corporation (now more commonly known as Powerball) in 1988, and the Big Game/Mega-Millions Association in 1996. By merging games, states could offer larger jackpots, but the increased number of players would assure that the grand prize was won on a regular basis.

Clotfelter and Cook (1993) suggest that the optimal (or at least most frequent) odds to population ratio for lotto games in the early 1990 s was roughly 1 . That is, a lottery association serving a population base of 13 million could offer a game with odds of roughly 1 in 13 million and maintain a reasonable frequency of jackpot winners. Until the early 2000 s, this meant that 
states with smaller populations generally offered lotto by being a member of one of the two major multi-state games (Powerball and Big Game/Mega-Millions) while more populous states could offer high prizes through independent lotto games. For example, as of January 2000, eight states (CA, TX, NY, FL, PA, OH, WA, and CO) operated lotto games but not did belong to a multi-state game. Of these eight states, six ranked among the seven largest states by population.

By the early 2000s, however, perhaps due to the record $\$ 250$ million plus jackpots offered during several Powerball and Mega-Millions drawings, even these hold-out states began to join in the multi-state associations so that by September 2004, only Florida and California remained independent from any multi-state lotto game. Similarly, the national lottery associations of the UK, France and Spain have joined together to offer EuroMillions, which promises to offer among the highest jackpots in Europe.

Lottery associations face numerous questions when posed with the option to join a multistate lottery. Essentially the choice is whether to join the multi-state game, offer an independent game, or sell tickets to both an independent game and the multi-state lotto game. The particular focus of this paper is the nature of the relationship between individual state-run games and the larger multi-state lotto games and whether they tend to be complements to or substitutes for one another.

The issue of complements/substitutes among lottery games is not new to the literature. Clotfelter and Cook (1989) test the effects of introducing lotto games on the sales of scratch-card tickets. Stover (1990) finds significant substitution effects between lotteries run by contiguous states. Gulley and Scott (1993), in part of a larger paper, consider the question of whether the two state lotto games in Massachuesetts, the Mass Millions and Mass Megabucks games, serve as substitutes for one another, finding no significant relationship between the two. Forrest, Gully 
and Simmons (2004) find evidence of some substitution among the variety of games offered by the United Kingdom National Lottery. Along the lines of these studies, this paper also attempts to answer the question of whether the various lottery products on the market are interrelated, but the focus will be on the relationship between multi-state lottery products and those offered by individual states in the states that offer both to their constituents.

\section{Substitutes vs. Complements}

The issue of whether multi-state and state lottery products are substitutes or complements to one another is perhaps not so straightforward as examining the lottery products of two different states as in Stover (1990). The lottery products of two different states are obviously in competition with one another as the states try to attract ticket buyers to their games and away from the products of the neighboring states in order to increase state revenues. When the multistate games of Powerball and Big Game/Mega Millions are considered next to the individuallyrun state games, however, the sense of competition is not nearly as strong since revenues from the ticket sales of Powerball and Mega Millions also stay within the state that sold it (both in form of revenue to the store that sold the ticket and to the state government that sponsors the game). Therefore, why concern one's self with whether the multi-state game is a substitute for a smaller state-run game or a complement to that game? Either way, the revenues from the games stay within that state, unlike when there are competing games from different states.

The reason for concern can be clarified by considering the purpose of offering a state lottery game in the first place. The games are offered to provide revenues to the state governments. If the games serve as substitutes for one another, then the increased sales in the multi-state game are offset (at least partially) by lower sales in the state game. If the two games 
serve as complements to one another, however, then ticket buyers increase purchases in the state game as the purchases rise in the multi-state game, and there are benefits from running the two games simultaneously.

How is it possible that lottery games could be either substitutes or complements to one another? If we were looking at two separate games where tickets were sold at different locations as in Stover (1990), there would be little question that the different games would be substitutes for one another. Ticket buyers would take their limited budgets devoted to ticket purchases and spend them where the expected return was higher (or effective ticket price was lower), after accounting for transaction costs. Since the tickets would have to be bought in different locations, there are no complementarities in the competing lotteries of different states.

However, while the potential for substitution between a multi-state and single state game still exists for a state that belongs to a multi-state association, there is also the possibility of complements arising as tickets can now be bought at the same store/location. Thus, as the larger multi-state jackpot rises to levels that the smaller state jackpots rarely (if ever) reach, consumers may buy tickets not only for the multi-state game from their local vendor but also for the local state game as well. This can be explained fairly easily through the consideration of transaction costs, expected returns, and consumer behavior. The relatively lower potential winnings from purchasing a smaller state lottery ticket may not be high enough to compel a potential buyer to go out and purchase a lottery ticket. However, the excitement generated by the substantially higher jackpots advertised in the multi-state games may be enough to attract ticket buyers to lottery vendors and also allows the consumer to overcome any psychological barriers to gambling. Once this occurs, the multi-state lottery ticket buyer may also indulge in the purchase of the small state lottery game as well. 
In a similar way, one might ask whether slot machines and table games at a casino are complements or substitutes. Suppose a particular casino is known for having particularly "loose" slots, that is their slot machines pay a high expected return. Certainly that casino would take business away from other neighborhood casinos just like lotto products from different states compete with one another. However, what would happen to revenue at the blackjack table within the casino with the loose slots? Would table revenue fall as casino patrons are lured away to slot machines, or would casino revenue rise as the loose slots lure new gamblers into the casino who then spend some portion of the time playing table games? It is this potential conflict of substitutes versus complements for competing lotto games offered within the same state that is examined in this paper.

\section{Gross Effect on State Lotto Sales as a Result of Joining a Multi-State Game}

The first question to be addressed is how the sales level of a state-run lotto game is affected once a state becomes a member of a larger multi-state game like Powerball or Mega Millions. Although this particular question is not directly correlated with the issue of whether the multi-state game is a complement or substitute for the state-run game according to the strict definitions of the two terms, it can provide an indication of how ticket buyers as a group respond to the additional (and larger jackpot) game, and particularly how that response affects the sales revenues of the smaller game.

The most obvious way to examine the gross effects of joining a multi-sate lottery would be to compare ticket sales from the state lotto game before the introduction of a new game to the combined ticket sales from both the state and multi-state lotto games after the adoption of a new game. There are two limits to this approach, however. First, state-by-state sales information for 
the larger multi-state games is not available for all states, precluding this as a general methodology. Second, and more importantly, there are likely other variables affecting the sales of a state's lottery tickets besides the presence of another lottery. To isolate the marginal effect of the presence of a multi-state lottery on the sales of a state lottery game, regression analysis can be used. In particular, one can determine the effect on the smaller game of the member lottery by regressing the sales for the game on a number of independent variables that should affect sales and including a dummy variable for the multi-state game once the state becomes a member. Once the marginal effect of the multi-state game on the state game is determined through regression analysis, the coefficient on the dummy variable can then be compared to the in-state sales generated by the multi-state game (where the data is available) to determine the net effect on sales revenues for the state. The equation used to estimate the effect of a multi-state games on state lotto ticket sales is shown in equation (1).

$$
\text { Sales }=\beta_{0}+\beta_{1}(\text { Jackpot })+\beta_{2}(\text { Jackpot })^{2}+\beta_{3}(\text { Trend })+\beta_{4}(\text { Multi-state })+\epsilon
$$

(Note: time subscripts for each variable have been dropped for simplicity.)

In addition to the Multi-state dummy variable, which takes on a value of 0 for drawings prior to becoming a multi-state game member and 1 thereafter, the advertised jackpot of the state game, advertised jackpot squared of the state game, and a time trend are also included in the first set of regressions. Since the price of a lotto ticket and the odds of winning remain fixed regardless of the size of the jackpot, the expected return from the purchase of a lottery ticket 
generally rises along with the size of the jackpot. ${ }^{1}$ It is therefore natural to assume that ticket sales will increase along with the advertised jackpot. "Jackpot squared" is also included as an explanatory variable to reflect the non-linear relationship between ticket sales and advertised jackpots. In general, ticket sales are predicted to increase at an increasing rate relative to the advertised jackpot. This reflects the growing excitement about large jackpots relative to smaller ones. . "Advertised jackpot" and "advertised jackpot squared" have been included in past academic articles such as DeBoer (1990), Shapira and Venezia (1992), Gulley and Scott (1993), Scott and Gulley (1995), Matheson (2001), and Forrest, et al, (2002), as primary explanatory variables for a lottery draw's sales.

A time trend variable is also included to account for the declining popularity in lottery products after they are introduced to the market. This phenomenon has also been examined in the literature by DeBoer (1990). For lotteries that have drawings twice a week (which is all of the lotteries examined in this paper), two separate regressions will be used as there is a distinct difference in the relationship between advertised jackpot levels and sales for drawings that involve sales of tickets over weekends versus those that only involve weekday drawings. This "day" effect for lotteries has been examined more closely in DeBoer (1990), among others.

The data used to estimate equation (1) are drawing by drawing sales for the lotto games of three individual state lottery associations that became members of either the Multi-State

\footnotetext{
${ }^{1}$ The exception to this rule comes from fact that if two or more tickets share the winning numbers, the jackpot prize is split among the winners. If the number of ticket buyers rises more rapidly than the jackpot, then the expected return may actually fall despite the larger grand-prize. This type of occurrence, known as "Lotto Fever," has been examined by Matheson and Grote (2004) and has been found to be exceedingly rare. Even on those rare occasions of "Lotto Fever," the excitement of extraordinarily high advertised jackpots entices the additional purchase of lottery tickets despite the lower expected value of the ticket.

${ }^{2}$ Note that the increasing sales relative to jackpots can either be explained by the same number of ticket buyers buying more tickets as jackpots rise or by more ticket buyers purchasing tickets as the higher jackpots increase expected returns enough to attract them to the market.
} 
Lottery Association (Powerball) or the multi-state Mega Millions game after they had operated as an independent lottery game. The three states and the dates they joined the multi-state games are Colorado (joined Powerball in 2001), New Jersey (joined Big Game/Mega Millions in 1999), and Ohio (joined Mega Millions in 2002). These three states were chosen for the availability of data as well as three other factors. First, each state added a multi-state game without making significant changes to their own state game at that time so that sales data for their state game are comparable before and after the addition of the multi-state game. Second, each state provided sufficient lotto sales data both before and after the adoption of the multi-state game to produce credible results. Finally, each state provided both sales data for their own state game as well as the sales within their own state for the multi-state game. Summary statistics for the three selected state lotto games are shown in Table 1.

The results of the regression analyses for equation (1) are provided in Table 2. All of the regressions showed significant evidence of positive first-order serial correlation so the variables used have been adjusted using the Cochrane-Orcutt process to diminish that effect. The DurbinWatson statistics of the original regressions and the rho values used to adjust the variables are included at the bottom of the tables.

The coefficients on the "Multi-state" dummy variables in Table 2 indicate that for each state lotto game considered, there is a statistically significant decline in sales for the state's own lotto game after it joins the multi-state game. In fact, the average sales for the each state game fell by at least $50 \%$ after the state began offering the multi-state game. This decline occurs even though the average jackpots for those same states have either remained the same or increased over those same time periods. 
While state lotto sales fell, in each case the magnitude of the multi-state dummy variable is significantly smaller than the average per drawing multi-state ticket revenues for each state. As shown in Table 1, on a per-drawing basis, the average sales for the multi-state game were over $\$ 790,000$ per drawing in Colorado, over $\$ 2,300,000$ per drawing in New Jersey, and roughly $\$ 1,700,000$ in Ohio. Comparing each of these numbers to the coefficient on the multi-state dummy variable for each game (which predicts the marginal impact on the sales per-drawing for the state game), one can readily determine that even though the states are predicted to have lost revenue on their own game due to the presence of the multi-state game, the increases in state revenues due to sales of multi-state tickets were greater than those losses. Thus, these three states seem to have increased overall state revenues by becoming members of the multi-state lottery.

Although adding a simple dummy variable for the time period during which a state also belongs to a multi-state game is a very straightforward approach to determining the effect on the sales of the smaller state lottery game, it may not be the most appropriate model. It is possible that with the addition of a new game, current purchasers of tickets for a state's own lotto game will not simply reduce their purchases by a fixed amount in each drawing, but will also alter their response to changing jackpot levels in the state game. For example, the excitement over a $\$ 50$ million state-lotto jackpot is likely to be considerably reduced given the availability of a multistate lottery that routinely hits jackpots many times this size. Thus, while ticket buyers should still respond to rising jackpots for the smaller state-run lotto games, it may be that their responses will be dampened after the addition of a larger and more dynamic multi-state game. This "dampening" effect can be measured by interacting the multi-state dummy variable with the 
Jackpot and Jackpot-Squared variables in the regression analysis. The second equation used to estimate the effect of a multi-state games on state lotto ticket sales is shown in equation (2).

$$
\text { Sales }=\beta_{0}+\beta_{1}(\mathrm{JP})+\beta_{2}(\mathrm{JP})^{2}+\beta_{3}(\text { Trend })+\beta_{4}(\mathrm{MS})+\beta_{4}(\mathrm{MS} x \mathrm{JP})+\beta_{5}(\mathrm{MS} \text { x JP})^{2}+\epsilon
$$

The regression results for equation (2) including this interaction effect are shown in Table 3. Once the dampening effect is included, an interesting result is revealed. For each state where the coefficient for the multi-state dummy variable is significantly different from zero, that coefficient is positive, not negative as was observed in Table 1. However, as the advertised jackpot for the state's lotto game increases, there is a significantly smaller increase in sales dollars (indicated by the negative sign on both of the interaction slope dummies) for every dollar added to the jackpot after the state joins a multi-state game. For example, in Wednesday drawings of the Colorado Lotto, prior to the introduction of Powerball, an increase in the jackpot from $\$ 1$ million to $\$ 2$ million increased ticket sales by about $\$ 161$ thousand; however, after the introduction of the multi-state game the same increase in the jackpot would only increase ticket sales by about $\$ 30$ thousand. At higher state jackpots, the resulting reductions in sales are even more pronounced. Similar results occur for each of the state lotteries examined and for each day of drawing under at least one of the two slope-dummy variables (if not both).

Taking all three dummy variables into account, one can ascertain that the lotto jackpot does not need to grow very high in order for the overall effect on state ticket sales to become negative in the post multi-state era. For example, considering the Colorado Wednesday drawing, the state lotto jackpot has to grow to only $\$ 1.3$ million dollars before the presence of the Powerball game begins to have a negative impact on Colorado's Wednesday drawing ticket 
sales. Since $\$ 1.3$ million dollars is just above Colorado's minimum jackpot prize of $\$ 1$ million, the presence of the Powerball game in Colorado is predicted to have an increasingly negative impact on the Wednesday drawing ticket sales for the Colorado lottery game as the state Lotto's jackpot rises.

The results presented here present evidence for "jackpot fatigue," the phenomenon experienced by many lotteries that large jackpots spur less and less ticket buying over time. Essentially, ticket buyers appear to be responding less to the relatively smaller advertised jackpots for the state games and more to the changing jackpots of the multi-state games, indicating that the addition of a "large jackpot" multi-state game does indeed attract consumers away from the smaller ones. In effect, the large multi-state games are responsible for jackpot fatigue in smaller state games. The results in Table 3, as a whole, also result in significantly higher F-scores and $\mathrm{R}^{2 \text { 's }}$ than the results in Table 2, although one must be careful in attributing too much significance to this since the variables have been adjusted for serial correlation.

In addition, if one uses the coefficients in Table 3 to estimate what ticket sales would have been in the three states had they not joined the multi-state game, these predictions can be compared to the combined actual sales of both state and multi-state lottery tickets to determine the net impact on state revenues. Using only the statistically significant coefficients on the three dummy variables for each game, the net impact on state revenues is consistently positive for the three states where data is available. The predicted average bi-weekly increase in revenues from combined ticket sales for the two games is over $\$ 400,000$ for Colorado, over $\$ 270,000$ for New Jersey, and over \$1.2 million dollars for Ohio. These are similar outcomes to what was determined from the first set of regressions in Table 1: the net effect on state revenues appears to be positive from the addition of the multi-state game. 


\section{Marginal Effect on State Sales from a Change in Jackpot of the Multi-State Game}

While the results of both Tables 2 and 3 show that the multi-state game attracts ticket buyers away from the smaller state games, indicating that the two games are likely to be substitutes for one another and not complements, one must be careful in interpreting the overall decline in the purchase of one item when another becomes available for the first time as indicating substitute goods. If substitutes are to be interpreted according to this manner, then essentially any good can be considered a substitute for any other good since consumers must necessarily give up the purchase of one item when they decide to purchase something new. After all, consumers are typically limited in their overall purchases by their income level and, if one expects such "substitutions" for seemingly unrelated goods, one should certainly expect it to happen for lottery games where consumers may limit spending on such recreational activities to an even smaller proportion of their overall income. It should not be surprising, therefore, that consumers in the states examined did, in fact, reduce their purchases of their own state's lottery tickets to buy the larger jackpot multi-state tickets with their limited incomes.

In order to determine whether the relationship between a state-run lotto game and its multi-state counterpart is one of substitutes or complements, one must do more than just consider the effect on sales when the state joins the multi-state game. The economic definition of substitutes and complements relies on an examination of the purchases of one good as the price changes for another not simply the effect on the sales of one good when another good is made available

Although the prices of lottery tickets do not change, the effective price of a ticket changes as the lottery jackpot rises. The equation for the effective price of a lottery ticket has been used 
in Gulley and Scott (1993), Scoggins (1995), and Forrest, Gulley and Simmons (2000) among others. It can be expressed using the equation:

$$
P=1-\left((1 / Q)(R+j Q)\left(1-e^{-Q p}\right)+E V s\right),
$$

where $\mathrm{P}$ is the effective price of the ticket, $\mathrm{Q}$ is the number of tickets sold, $\mathrm{R}$ is the rollover to the jackpot prize pool from the previous drawing, $\mathrm{j}$ is the proportion of sales revenue allocated to the jackpot, $\mathrm{p}$ is the probability of a ticket winning the jackpot and EVs is the expected value of the smaller prizes. The expression $\left(1-\mathrm{e}^{-\mathrm{Qp}}\right)$ in the formula accounts for the probability of having to share the jackpot with another winning ticket. As the number of tickets sold increases, the probability of having to share the jackpot with another winning ticket rises. This lowers the expected value of a lottery ticket purchase and, therefore, increases the effective price of a ticket.

While the effective price of a lottery ticket will not be estimated in the current analysis, what is important in considering equation (3) is the relationship between the rollover term and the effective price: as the rollover increases, the effective price of a ticket falls for a given level of sales and given odds of winning the prize(s). Therefore, one can examine the change in the advertised jackpot (as a result of the rollover from the previous draw) of one game compared to the change in sales of the other to explore the nature of the relationship between the two games. If, as the jackpot increases (and the effective price falls) in one game, the draw sales in another rise, ceteris paribus, this is evidence that the two lotteries are complements to one another as ticket buyers buy more tickets in both lottery games. If the opposite relationship holds and draw sales fall as the effective price in the other game decreases, the two lotteries appear to be 
substitutes for one another as ticket buyers choose to buy more tickets in the lotto game with the lower effective price and less in the other.

Since, as mentioned previously, state-by-state sales for the multi-state lotteries are not readily available for all states, and since no single state comprises a significant portion of total Powerball or Big Game/Mega-Millions sales, only the effects of multi-state lottery jackpots on single-state lottery sales will be tested and not vice versa.

The data requirements to test for the effects of the multi-state jackpot on single state sales are different than those to test the effects of the adoption of a multi-state lottery on single state sales. First, it is not necessary for a state to have operated their own lotto game both before and after joining a multi-state game, increasing the possible number of states that could be examined. Second, it is important that the drawings for the state and the multi-state games occur on the same day. Since ticket sales data are available drawing-by-drawing and not day-by-day, if the multi-state lottery has different drawing days than the state game, local buyers will face two different multi-state jackpots over the course of the state lotto drawing period. Powerball drawings occur on Wednesday and Saturday, making Colorado usable, while Big Game/Mega Millions occur on Tuesday and Friday, excluding New Jersey and Ohio. Fortunately, additional data are available for lotto games in Indiana, Missouri, South Dakota, Wisconsin, and for Hot Lotto, itself a multi-state game sold in eight smaller states concurrently with Powerball. Summary statistics for the six selected state lotto games are shown in Table 4.

The final equation used to estimate the effect of a multi-state games on state lotto ticket sales is shown in equation (4).

$$
\text { Sales }=\beta_{0}+\beta_{1}(\text { Jackpot })+\beta_{2}(\text { Jackpot })^{2}+\beta_{3}(\text { Trend })+\beta_{4}(\text { PBJP })+\beta_{4}(\text { PBJP })^{2}+\epsilon
$$


where Sales is ticket sales for the state game, Jackpot is the advertised jackpot of the state game, and PBJP is the advertised jackpot of the multi-state Powerball game.

The regression results from equation (4) are presented in Tables 5.1 and 5.2 and provide the clearest results for understanding the relationship between a large multi-state game and a smaller state lotto game. In seven of the twelve games examined, the coefficients on both the PBJP and PBJP-squared terms are positive with at least one of the coefficients statistically significant at the $10 \%$ level. In these cases, since state lotto sales rise as the Powerball jackpot rises (and hence the effective price of a Powerball ticket falls), the results provide clear evidence that the multi-state game is a complementary good to the state game.

In cases where the signs on the PBJP and PBJP-squared terms are different, care must be taken in interpreting the results. In three of the remaining five cases the positive coefficient is statistically significant at the $5 \%$ level or above while the negative coefficient is not statistically significantly different from zero, so again in these cases, persuasive evidence is provided that Powerball is a complement to the smaller game.

In the final two cases, the coefficients on the two terms are both statistically significant but of opposite signs. In these cases, one can simply combine the effects of the two coefficients. For example, in the South Dakota Wednesday drawing, the coefficient on the PBJP term is 25.97 while the coefficient on the PBJP-squared term is -0.037 . At a Powerball jackpot of $\$ 50$ million, for example, the expected sales in the South Dakota Lotto would rise by 1,206 tickets ( $=25.97 \mathrm{x}$ $50-0.037 \times 50^{2}$ ), or $8.78 \%$ relative to the average sales for the South Dakota Wednesday drawings. For the South Dakota Wedensday drawing, the net effect of PBJP and PBJP-squared are positive for all Powerball jackpots less than $\$ 700$ million, a figure nearly three times larger 
than any Powerball jackpot yet observed. Again, the multi-state game is shown to be a complement to the state game over the range of observed Powerball jackpots.

In the Wisconsin Lotto Saturday drawing there is a negative and significant Jackpot term for Powerball, but a positive and significant Jackpot-squared term for Powerball. Using similar reasoning, this indicates the multi-state game is a substitute at lower Powerball jackpots, but as that jackpot rises to higher levels (of roughly $\$ 100$ million or more), the relationship becomes one of complements. Overall, the combined results of Tables 5.1 and 5.2 provide strong evidence that a large multi-state lottery game tends to be a complement to a smaller state games, attracting more buyers to both games as its jackpot increases.

While this may seem to contradict the evidence for substitution effects when the multistate game is new introduced in the previous sets of results, indeed the results of all three models are consistent with one another. As stated above, in order for two goods to be substitutes, one does not consider the overall effect on sales when a new product is introduced to a market. Rather one considers the sales of one good as the price changes on the other. A rising multi-state lottery jackpot results in a lower effective price of a multi-state lottery ticket, and, as is observed in eleven of the twelve lottery games examined, there is a positive and statistically significant impact on sales of a state's lottery tickets as the effective price of a Powerball ticket falls. This is evidence of complementary goods in those eleven lottery games. In the remaining game, the two games were complements for one another over some, but not all, Powerball jackpot levels.

\section{Section IV: Conclusions}

There is little doubt that smaller state-run games lose ticket buyers when a state joins a multi-state lottery association. Furthermore, following the introduction of a multi-state game, 
ticket buyers within a state become less responsive to changes in the state lotto game leading to "jackpot fatigue." However, since the proceeds from both types of games stay within the state that sells the tickets, this should not be the only or even the primary consideration when states decide to become a part of a multi-state game. The evidence suggests that the combined ticket sales of the state and multi-state game rise when a multi-state game is introduced. A final issue is how ticket buyers react to changes in the effective price of the larger lottery when they make their ticket buying decisions for the smaller one. Evidence in this paper tends to show that the complementary effects of the two games tend to dominate in eleven of the twelve games considered. In the only game where it appears there are substitution effects, this occurs only at lower jackpot levels, but then the games become complements at higher jackpot levels for the multi-state game.

What this means for states that run their own lottery games is twofold. First, the state indeed benefits overall from belonging to a multi-state game even if the smaller state-run game sees a gross decline in sales as a result. Second, state lottery associations need to, and often do, promote the larger games as much as possible in their advertising efforts to attract buyers to the ticket realtors in the first place. Once there, it appears that ticket buyers tend to take advantage of the opportunity of participating in the smaller state game in addition to their purchases of the multi-state game ticket. Indeed, states may wish to take advantage of the frenzy created by the large jackpots touted by multi-state games by offering other complementary products that can "piggy-back" on the success of Powerball or the Big Game/Mega-Millions lottery. 


\section{REFERENCES}

Clotfelter, Charles T. and Cook, Philip J. Selling Hope. Cambridge, MA: Harvard University Press, 1989.

Clotfelter Charles T. and Cook, Philip J. "The Peculiar Scale Economies of Lotto," American Economic Review, June 1993, 83:3, 634-643.

DeBoer, Larry. “Lotto Sales Stagnation: Product Maturity or Small Jackpots?” Growth and Change, Winter 1990, 73-7.

Forrest, David, Gulley, O. David and Simmons, Robert. "Elasticity of Demand for UK National Lottery Tickets," National Tax Journal, December 2000, 853 - 63.

Forrest, David, Gulley, O. David and Simmons, Robert. "Substitution between Games in the UK National Lottery," Applied Economics, April 2004, 645-51.

Forrest, David, Simmons, Robert and Chesters, N. " Buying a Dream: Alternative Models of Demand for Lotto,” Economic Inquiry, 40:3, July 2002, 485-96.

Gully, O. David and Scott, Frank A., Jr. "The Demand for Wagering on State-Operated Lotto Games," National Tax Journal. March 1993, 13-22.

Matheson, Victor A. "When are State Lotteries a Good Bet? (Revisited)," Eastern Economic Journal, Winter 2001, 55-70.

Matheson, Victor A. and Grote, Kent R. "Lotto Fever: Do Lottery Players Act Rationally Around Large Jackpots?” Economics Letters, May 2004, 233-7.

Novarro, Neva. "Earmarked Lottery Profits: A Good Bet for Education Finance?" Journal of Education Finance, forthcoming, 2005.

Scoggins, John F. “The Lotto and Expected Net Revenue," National Tax Journal, March 1995, 61-70.

Scott, Frank A., Jr. and Gully, O. David. "Testing for Efficiency in Lotto Markets," Economic Inquiry, April 1995, 175-88.

Shapira, Zur and Venezia, Itzhak. "Size and Frequency of Prizes as Determinants of the Demand for Lotteries" Organizational Behavior and Human Decision Processes, July 1992, 307-18.

Stover, M.E. “Contiguous State Lotteries: Substitutes or Complements?” Journal of Policy Analysis and Management, 1990, 565-8. 
Table 1: Summary Statistics for Data used in first two regression models

$\begin{array}{cccccccccc} & \text { Dates } & \text { Number of } & \text { Mean } & \text { Minimum } & \text { Maximum } & \text { Mean } & \text { Minimum } & \text { Maximum } & \text { Mean } \\ \text { Lottery Game } & \text { Covered } & \text { Observations } & \text { Sales } & \text { Sales } & \text { Sales } & \text { Jackpot* } & \text { Jackpot* } & \text { Jackpot* } & \text { MS Sales }\end{array}$

Pre Multi-state:

Colorado

$7 / 14 / 90-8 / 4 / 01$

$\begin{array}{rr}1151 & 1,245,818 \\ 407 & 3,189,415 \\ 1182 & 3,817,820\end{array}$

$\begin{array}{rr}528,779 & 9,297,945 \\ 1,306,790 & 21,770,479 \\ 1,014,356 & 19,291,293 \\ & \\ & \\ 265,292 & 1,000,848 \\ 855,338 & 6,553,945 \\ 995,565 & 3,005,028\end{array}$

3.98
5.48
11.36

$\begin{array}{rl}1.5 & 27 \\ 2 & 35 \\ 4 & 75\end{array}$

Post Multi-state:

\section{Colorado}

$8 / 8 / 01-6 / 19 / 04$

$5 / 27 / 99-6 / 21 / 04$

$\begin{array}{lr}299 & 459,566 \\ 530 & 1,576,863 \\ 220 & 1,485,420\end{array}$

995,565

$3,005,028$

3.85
9.02
11.85

16
48.5
37

790,516

$2,330,984$

$1,704,523$

* Numbers are in millions of dollars. 
Table 2: Presence of Multi-State Game 1

\begin{tabular}{|c|c|c|c|c|c|c|}
\hline & Colorado & Colorado & New Jersey & New Jersey & Ohio & Ohio \\
\hline Variable & Weds & Sat & Mon & Thurs & Weds & Sat \\
\hline Constant & $\begin{array}{r}393,939^{* *} \\
(17.07)\end{array}$ & $\begin{array}{r}589,647^{* *} \\
(23.90)\end{array}$ & $\begin{array}{r}1,642,509^{* *} \\
(19.63)\end{array}$ & $\begin{array}{r}1,987,502^{* *} \\
(16.46)\end{array}$ & $\begin{array}{r}2,109,484^{* *} \\
(26.00)\end{array}$ & $\begin{array}{r}2,269,476^{* *} \\
(29.61)\end{array}$ \\
\hline Jackpot & $\begin{array}{r}107,111^{* *} \\
(14.01)\end{array}$ & $\begin{array}{r}54,368^{* *} \\
(5.85)\end{array}$ & $\begin{array}{r}238,371^{* *} \\
(16.46)\end{array}$ & $\begin{array}{r}200,719^{* *} \\
(9.74)\end{array}$ & $\begin{array}{l}92,500^{* *} \\
(9.02)\end{array}$ & $\begin{array}{r}140,449^{* *} \\
(16.90)\end{array}$ \\
\hline Jackpot $^{2}$ & $\begin{array}{l}7,648^{* *} \\
(16.33)\end{array}$ & $\begin{array}{c}11,583^{* *} \\
(17.80)\end{array}$ & $\begin{array}{r}-3,587^{* *} \\
(-8.80)\end{array}$ & $\begin{array}{c}-1,744^{* *} \\
(-3.01)\end{array}$ & $\begin{array}{l}3,852^{* *} \\
(14.11)\end{array}$ & $\begin{array}{r}1,885^{* *} \\
(9.41)\end{array}$ \\
\hline Time & $\begin{array}{c}-747.1^{* *} \\
(-5.80)\end{array}$ & $\begin{array}{c}-948.4^{* *} \\
(-8.24)\end{array}$ & $\begin{array}{c}-4,034^{* *} \\
(-5.56)\end{array}$ & $\begin{array}{c}-5,031^{* *} \\
(-5.06)\end{array}$ & $\begin{array}{l}-4,396^{* *} \\
(-15.05)\end{array}$ & $\begin{array}{l}-4,664^{* *} \\
(-16.84)\end{array}$ \\
\hline Multi-state & $\begin{array}{r}-441,764^{* *} \\
(-6.72)\end{array}$ & $\begin{array}{r}-442,392^{* *} \\
(-7.58)\end{array}$ & $\begin{array}{r}-1,033,907^{* *} \\
(-5.27)\end{array}$ & $\begin{array}{r}-1,025,619^{* *} \\
(-3.77)\end{array}$ & $\begin{array}{r}-805,712^{* *} \\
(-4.99)\end{array}$ & $\begin{array}{r}-797,393^{* *} \\
(-5.23)\end{array}$ \\
\hline $\mathrm{N}$ & 723 & 725 & 467 & 468 & 699 & 701 \\
\hline R-square & 0.869 & 0.855 & 0.64 & 0.535 & 0.850 & 0.839 \\
\hline Adj. R-square & 0.869 & 0.854 & 0.637 & 0.531 & 0.849 & 0.838 \\
\hline $\mathrm{F}$ & $1,194.3^{* *}$ & $1,062.2^{* *}$ & $205.6^{* *}$ & $133.3^{* *}$ & $982.4^{* *}$ & $905.4^{* *}$ \\
\hline DW & 0.979 & 1.109 & 1.367 & 1.425 & 1.317 & 1.348 \\
\hline Rho & 0.51 & 0.445 & 0.316 & 0.287 & 0.341 & 0.326 \\
\hline
\end{tabular}

The number in parentheses below each coefficient is the respective t-score for that coefficient.

${ }^{* *}$ Significant at $1 \%$ level

* Significant at 5\% level 
Table 3: Presence of Multi-State Game 2

\begin{tabular}{|c|c|c|c|c|c|c|c|c|}
\hline Variable & $\begin{array}{l}\text { Colorado } \\
\text { Weds }\end{array}$ & $\begin{array}{c}\text { Colorado } \\
\text { Sat }\end{array}$ & $\begin{array}{c}\text { New Jersey } \\
\text { Mon }\end{array}$ & $\begin{array}{c}\text { New Jersey } \\
\text { Thurs }\end{array}$ & $\begin{array}{l}\text { Ohio } \\
\text { Weds }\end{array}$ & $\begin{array}{l}\text { Ohio } \\
\text { Sat }\end{array}$ & $\begin{array}{l}\text { Texas } \\
\text { Weds }\end{array}$ & $\begin{array}{c}\text { Texas } \\
\text { Sat }\end{array}$ \\
\hline Constant & $\begin{array}{r}420,590^{* *} \\
(23.92)\end{array}$ & $\begin{array}{r}608,115^{* *} \\
(33.05)\end{array}$ & $\begin{array}{r}1,236,203^{* *} \\
(27.25)\end{array}$ & $\begin{array}{r}1,258,763^{* *} \\
(33.02)\end{array}$ & $\begin{array}{r}2,225,675^{* *} \\
(31.16)\end{array}$ & $\begin{array}{r}2,484,017^{* *} \\
(36.41)\end{array}$ & $\begin{array}{r}5,427,976^{* *} \\
(43.45)\end{array}$ & $\begin{array}{r}5,491,149^{* *} \\
(47.68)\end{array}$ \\
\hline Jackpot & $\begin{array}{r}140,039^{* *} \\
(23.21)\end{array}$ & $\begin{array}{r}80,545^{* *} \\
(11.38)\end{array}$ & $\begin{array}{r}244,573^{* *} \\
(18.14)\end{array}$ & $\begin{array}{r}153,915^{* *} \\
(15.35)\end{array}$ & $\begin{array}{r}118,965^{* *} \\
(13.46)\end{array}$ & $\begin{array}{r}166,905^{* *} \\
(23.19)\end{array}$ & $\begin{array}{r}136,986^{* *} \\
(11.94)\end{array}$ & $\begin{array}{r}151,513^{* *} \\
(12.64)\end{array}$ \\
\hline Jackpot $^{2}$ & $\begin{array}{l}6,971^{* *} \\
(19.30)\end{array}$ & $\begin{array}{c}11,481^{* *} \\
(23.56)\end{array}$ & $\begin{array}{r}3,357^{* *} \\
(5.97)\end{array}$ & $\begin{array}{l}9,488^{* *} \\
(26.71)\end{array}$ & $\begin{array}{l}3,629^{* *} \\
(15.69)\end{array}$ & $\begin{array}{l}1,696^{* *} \\
(10.02)\end{array}$ & $\begin{array}{l}4,725^{* *} \\
(22.73)\end{array}$ & $\begin{array}{l}3,981^{* *} \\
(16.57)\end{array}$ \\
\hline Time & $\begin{array}{l}-837.1^{* *} \\
(-10.70)\end{array}$ & $\begin{array}{l}-1,020^{* *} \\
(-14.09)\end{array}$ & $\begin{array}{l}-4,371^{* *} \\
(-11.39)\end{array}$ & $\begin{array}{l}-4,560^{* *} \\
(-11.46)\end{array}$ & $\begin{array}{c}4,428^{* *} \\
(-21.23)\end{array}$ & $\begin{array}{l}-4,715^{* *} \\
(-24.60)\end{array}$ & $\begin{array}{r}-12,978^{* *} \\
(-25.65)\end{array}$ & $\begin{array}{c}-12,016^{* *} \\
(-26.32)\end{array}$ \\
\hline Multi-state & $\begin{array}{r}156,007^{* *} \\
(2.44)\end{array}$ & $\begin{array}{r}5290 \\
(0.08)\end{array}$ & $\begin{array}{r}475,634^{* *} \\
(3.81)\end{array}$ & $\begin{array}{r}220,697 \\
(1.79)\end{array}$ & $\begin{array}{r}945,452^{* *} \\
(3.45)\end{array}$ & $\begin{array}{r}1,184,313^{* *} \\
(4.71)\end{array}$ & $\begin{array}{r}3,079,134^{* *} \\
(4.83)\end{array}$ & $\begin{array}{r}1,841,454^{* *} \\
(3.32)\end{array}$ \\
\hline MS x Jackpot & $\begin{array}{r}-110,070^{* *} \\
(-5.26)\end{array}$ & $\begin{array}{r}-34,885 \\
(-1.56)\end{array}$ & $\begin{array}{r}-179,043^{* *} \\
(-10.95)\end{array}$ & $\begin{array}{r}-89,866^{* *} \\
(-6.79)\end{array}$ & $\begin{array}{r}-97,342^{*} \\
(-2.5)\end{array}$ & $\begin{array}{r}-145,341^{* *} \\
(-4.28)\end{array}$ & $\begin{array}{r}-243,449^{* *} \\
(-7.54)\end{array}$ & $\begin{array}{r}-156,409^{* *} \\
(-6.20)\end{array}$ \\
\hline MS $x$ Jackpot ${ }^{2}$ & $\begin{array}{r}-6,823^{* *} \\
(-4.26)\end{array}$ & $\begin{array}{r}-12,453^{* *} \\
(-7.17)\end{array}$ & $\begin{array}{r}-3,544^{* *} \\
(-5.79)\end{array}$ & $\begin{array}{l}-9,641^{* *} \\
(-22.88)\end{array}$ & $\begin{array}{r}-3,229^{* *} \\
(-2.74)\end{array}$ & $\begin{array}{l}-1,252 \\
(-1.30)\end{array}$ & $\begin{array}{r}-2,187^{* *} \\
(-6.36)\end{array}$ & $\begin{array}{r}-2,682^{* *} \\
(-9.19)\end{array}$ \\
\hline $\mathrm{N}$ & 723 & 725 & 467 & 468 & 699 & 701 & 612 & 612 \\
\hline R-square & 0.931 & 0.928 & 0.917 & 0.956 & 0.902 & 0.896 & 0.927 & 0.916 \\
\hline Adj. R-square & 0.931 & 0.927 & 0.916 & 0.955 & 0.901 & 0.895 & 0.926 & 0.915 \\
\hline $\mathrm{F}$ & $1,622.6^{* *}$ & $1,537.7^{* *}$ & $845.9^{* *}$ & $1,666.0^{* *}$ & $1,063.2^{* *}$ & $997.3^{* *}$ & $1,276.6^{* *}$ & $1,098.9^{* *}$ \\
\hline DW & 1.174 & 1.236 & 1.224 & 1.068 & 1.505 & 1.595 & 1.302 & 1.318 \\
\hline Rho & 0.412 & 0.381 & 0.388 & 0.466 & 0.247 & 0.203 & 0.344 & 0.335 \\
\hline
\end{tabular}

The number in parentheses below each coefficient is the respective t-score for that coefficient.

${ }^{* *}$ Significant at $1 \%$ level

${ }^{*}$ Significant at $5 \%$ level 
Table 4: Summary Statistics for Data used in third regression model

\begin{tabular}{|c|c|c|c|c|c|c|c|c|}
\hline Lottery Game & $\begin{array}{c}\text { Dates } \\
\text { Covered }\end{array}$ & $\begin{array}{l}\text { Number of } \\
\text { Observations }\end{array}$ & $\begin{array}{l}\text { Mean } \\
\text { Sales }\end{array}$ & $\begin{array}{l}\text { Minimum } \\
\text { Sales }\end{array}$ & $\begin{array}{l}\text { Maximum } \\
\text { Sales }\end{array}$ & $\begin{array}{c}\text { Mean } \\
\text { Jackpot* }\end{array}$ & $\begin{array}{l}\text { Minimum } \\
\text { Jackpot* }\end{array}$ & $\begin{array}{c}\text { Maximum } \\
\text { Jackpot* }\end{array}$ \\
\hline Colorado Weds & $8 / 8 / 01-6 / 16 / 04$ & 150 & 438,533 & 265,292 & 854,093 & 3.78 & 1 & 16 \\
\hline Colorado Sat & $8 / 4 / 01-6 / 19 / 04$ & 150 & 481,694 & 326,582 & $1,000,848$ & 3.93 & 1 & 15 \\
\hline Hot Lotto Weds & $4 / 10 / 02-7 / 7 / 04$ & 117 & 246,116 & 180,665 & 492,400 & 2.12 & 1 & 6.02 \\
\hline Hot Lotto Sat & $4 / 13 / 02-7 / 10 / 04$ & 117 & 256,560 & 184,382 & 529,264 & 2.11 & 1 & 6.23 \\
\hline Indiana Weds & $2 / 18 / 98-6 / 16 / 04$ & 330 & 580,062 & 387,329 & $1,761,575$ & 6.87 & 1 & 40 \\
\hline Indiana Sat & $2 / 21 / 98-6 / 19 / 04$ & 330 & 846,279 & 552,098 & $2,387,287$ & 6.85 & 1 & 42 \\
\hline Missouri Weds & $1 / 3 / 96-5 / 19 / 99$ & 176 & 267,580 & 202,292 & 492,348 & 2.72 & 1 & 11.6 \\
\hline Missouri Sat & $1 / 6 / 96-5 / 22 / 99$ & 176 & 312,236 & 214,441 & 552,508 & 2.71 & 1 & 11.3 \\
\hline South Dakota Weds & $7 / 3 / 96-6 / 23 / 04$ & 414 & 13,739 & 4,691 & 35,208 & 0.06 & 0.02 & 0.34 \\
\hline South Dakota Sat & $7 / 6 / 96-6 / 26 / 04$ & 414 & 15,783 & 9,014 & 36,003 & 0.07 & 0.02 & 0.33 \\
\hline Wisconsin Weds & $6 / 21 / 95-6 / 16 / 04$ & 469 & 221,282 & 142,339 & $1,466,579$ & 3.98 & 1 & 18.5 \\
\hline Wisconsin Sat & 6/17/95 - 6/19/04 & 470 & 242,850 & 156,938 & $1,887,161$ & 4.01 & 1 & 20.3 \\
\hline
\end{tabular}

* Numbers are in millions of dollars. 
Table 5.1: Effect of Changing Multi-State Jackpot

\begin{tabular}{|c|c|c|c|c|c|c|}
\hline Variable & $\begin{array}{l}\text { Colorado } \\
\text { Weds }\end{array}$ & $\begin{array}{c}\text { Colorado } \\
\text { Sat }\end{array}$ & $\begin{array}{l}\text { Hot Lotto } \\
\text { Weds }\end{array}$ & $\begin{array}{c}\text { Hot Lotto } \\
\text { Sat }\end{array}$ & $\begin{array}{l}\text { Indiana } \\
\text { Weds }\end{array}$ & $\begin{array}{c}\text { Indiana } \\
\text { Sat }\end{array}$ \\
\hline Constant & $\begin{array}{r}93,799^{* *} \\
(20.24)\end{array}$ & $\begin{array}{r}231,279^{* *} \\
(21.54)\end{array}$ & $\begin{array}{r}44,370^{* *} \\
(13.04)\end{array}$ & $\begin{array}{r}104,955^{* *} \\
(15.47)\end{array}$ & $\begin{array}{r}160,184^{* *} \\
(30.61)\end{array}$ & $\begin{array}{r}213,728^{* *} \\
(33.82)\end{array}$ \\
\hline Jackpot & $\begin{array}{c}35,760^{* *} \\
(13.04)\end{array}$ & $\begin{array}{r}35,881^{* *} \\
(7.07)\end{array}$ & $\begin{array}{l}-292.7 \\
(-0.05)\end{array}$ & $\begin{array}{l}-3,998 \\
(-0.44)\end{array}$ & $\begin{array}{r}14,622^{* *} \\
(11.29)\end{array}$ & $\begin{array}{r}14,333^{* *} \\
(9.03)\end{array}$ \\
\hline Jackpot $^{2}$ & $\begin{array}{l}-229.6 \\
(-1.08)\end{array}$ & $\begin{array}{l}-263.3 \\
(-0.66)\end{array}$ & $\begin{array}{r}8,255^{* *} \\
(7.11)\end{array}$ & $\begin{array}{r}8,988^{* *} \\
(5.83)\end{array}$ & $\begin{array}{r}429.8^{* *} \\
(9.23)\end{array}$ & $\begin{array}{l}588.3^{* *} \\
(11.00)\end{array}$ \\
\hline Time & $\begin{array}{r}-362.9^{* *} \\
(-4.24)\end{array}$ & $\begin{array}{r}-862.3^{* *} \\
(-5.88)\end{array}$ & $\begin{array}{l}-14.24 \\
(-0.11)\end{array}$ & $\begin{array}{l}-131.9 \\
(-1.17)\end{array}$ & $\begin{array}{r}-451.4^{* *} \\
(-5.95)\end{array}$ & $\begin{array}{l}-1,289^{* *} \\
(-10.08)\end{array}$ \\
\hline PB Jackpot & $\begin{array}{l}62.31 \\
(0.47)\end{array}$ & $\begin{array}{r}-143.82 \\
(-0.68)\end{array}$ & $\begin{array}{l}-24.51 \\
(-0.49)\end{array}$ & $\begin{array}{l}-90.16 \\
(-0.77)\end{array}$ & $\begin{array}{l}353.8^{*} \\
(2.21)\end{array}$ & $\begin{array}{l}245.6 \\
(1.25)\end{array}$ \\
\hline PB Jackpot ${ }^{2}$ & $\begin{array}{r}2.104^{* *} \\
(3.45)\end{array}$ & $\begin{array}{r}2.266^{* *} \\
(2.65)\end{array}$ & $\begin{array}{r}1.157^{* *} \\
(5.31)\end{array}$ & $\begin{array}{l}1.206^{*} \\
(2.04)\end{array}$ & $\begin{array}{r}4.230^{* *} \\
(6.05)\end{array}$ & $\begin{array}{r}3.634^{* *} \\
(3.97)\end{array}$ \\
\hline $\mathrm{N}$ & 150 & 150 & 117 & 117 & 330 & 330 \\
\hline R-square & 0.905 & 0.801 & 0.872 & 0.77 & 0.965 & 0.853 \\
\hline Adj. R-square & 0.901 & 0.794 & 0.866 & 0.76 & 0.964 & 0.851 \\
\hline $\mathrm{F}$ & $273.0^{* *}$ & $116.0^{* *}$ & $150.6^{* *}$ & $74.4^{* *}$ & $1468.9^{* *}$ & $376.4^{* *}$ \\
\hline DW & 0.517 & 1.102 & 0.401 & 0.798 & 0.65 & 0.465 \\
\hline Rho & 0.732 & 0.432 & 0.769 & 0.523 & 0.675 & 0.76 \\
\hline
\end{tabular}

The number in parentheses below each coefficient is the respective t-score for that coefficient.

${ }^{* *}$ Significant at $1 \%$ level

${ }^{*}$ Significant at $5 \%$ level 
Table 5.2: Effect of Changing Multi-State Jackpot

\begin{tabular}{|c|c|c|c|c|c|c|}
\hline Variable & $\begin{array}{l}\text { Missouri } \\
\text { Weds }\end{array}$ & $\begin{array}{c}\text { Missouri } \\
\text { Sat }\end{array}$ & $\begin{array}{l}\text { South Dakota } \\
\text { Weds }\end{array}$ & $\begin{array}{c}\text { South Dakota } \\
\text { Sat }\end{array}$ & $\begin{array}{l}\text { Wisconsin } \\
\text { Weds }\end{array}$ & $\begin{array}{c}\text { Wisconsin } \\
\text { Sat }\end{array}$ \\
\hline Constant & $\begin{array}{r}93,493^{* *} \\
(22.58)\end{array}$ & $\begin{array}{r}123,286^{* *} \\
(28.61)\end{array}$ & $\begin{array}{l}3,635^{* *} \\
(23.00)\end{array}$ & $\begin{array}{l}1,852^{* *} \\
(14.18)\end{array}$ & $\begin{array}{r}94,193^{* *} \\
(18.58)\end{array}$ & $\begin{array}{r}112,365^{* *} \\
(23.50)\end{array}$ \\
\hline Jackpot & $\begin{array}{r}25,529^{* *} \\
(7.72)\end{array}$ & $\begin{array}{r}25,121^{* *} \\
(7.23)\end{array}$ & $\begin{array}{r}56,940^{* *} \\
(9.12)\end{array}$ & $\begin{array}{r}80,152^{* *} \\
(14.65)\end{array}$ & $\begin{array}{l}-6,045^{*} \\
(-2.12)\end{array}$ & $\begin{array}{r}-9,058^{* *} \\
(-3.25)\end{array}$ \\
\hline Jackpot $^{2}$ & $\begin{array}{l}-41.17 \\
(-0.14)\end{array}$ & $\begin{array}{r}62.71 \\
(0.18)\end{array}$ & $\begin{array}{r}15,593 \\
(0.64)\end{array}$ & $\begin{array}{r}-40,188 \\
(-1.88)\end{array}$ & $\begin{array}{l}2,020^{* *} \\
(10.26)\end{array}$ & $\begin{array}{l}2,227^{* *} \\
(11.79)\end{array}$ \\
\hline Time & $\begin{array}{r}-281.4^{* *} \\
(-4.22)\end{array}$ & $\begin{array}{r}-430.0^{* *} \\
(-6.50)\end{array}$ & $\begin{array}{l}-34.36^{* *} \\
(-12.67)\end{array}$ & $\begin{array}{r}-9.144^{* *} \\
(-2.68)\end{array}$ & $\begin{array}{r}-95.36^{* *} \\
(-3.23)\end{array}$ & $\begin{array}{r}-105.2^{* *} \\
(-3.44)\end{array}$ \\
\hline PB Jackpot & $\begin{array}{r}423.5^{* *} \\
(3.39)\end{array}$ & $\begin{array}{r}273.6^{\dagger} \\
(1.84)\end{array}$ & $\begin{array}{l}25.97^{* *} \\
(10.74)\end{array}$ & $\begin{array}{l}4.729 \\
(1.13)\end{array}$ & $\begin{array}{l}283.5^{*} \\
(2.16)\end{array}$ & $\begin{array}{r}-1,022^{* *} \\
(-7.20)\end{array}$ \\
\hline PB Jackpot ${ }^{2}$ & $\begin{array}{l}0.455 \\
(0.80)\end{array}$ & $\begin{array}{r}0.324 \\
(0.31)\end{array}$ & $\begin{array}{l}-0.037^{*} \\
(-2.44)\end{array}$ & $\begin{array}{r}0.060^{* *} \\
(3.05)\end{array}$ & $\begin{array}{l}1.033^{\dagger} \\
(1.88)\end{array}$ & $\begin{array}{l}10.06^{* *} \\
(13.85)\end{array}$ \\
\hline $\mathrm{N}$ & 176 & 176 & 414 & 414 & 469 & 470 \\
\hline R-square & 0.785 & 0.777 & 0.711 & 0.784 & 0.645 & 0.785 \\
\hline Adj. R-square & 0.779 & 0.77 & 0.707 & 0.781 & 0.641 & 0.783 \\
\hline F & $124.1^{* *}$ & $118.3^{* *}$ & $200.8^{* *}$ & $296.0^{* *}$ & $168.4^{* *}$ & $339.0^{* *}$ \\
\hline DW & 0.877 & 0.898 & 0.456 & 0.293 & 0.948 & 0.892 \\
\hline Rho & 0.56 & 0.551 & 0.77 & 0.85 & 0.526 & 0.554 \\
\hline
\end{tabular}

